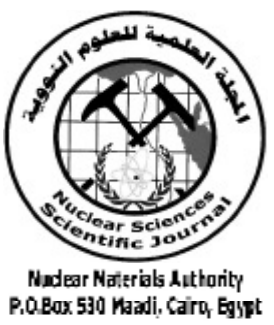

ISSN 2314-5609

Nuclear Sciences Scientific Journal

vol. 3, p 169 - 179

2014

\title{
PRODUCTION OF COMMERCIAL URANIUM CONCENTRATE FROM EL-SELA SHEAR ZONE MINERALIZED ORE MATERIAL, SOUTH EASTERN DESERT - EGYPT, AT INSHAS PILOT PLANT UNIT
}

\author{
YASSER M. KHAWASSEK \\ Nuclear Materials Authority, Egypt
}

\begin{abstract}
This paper is concerned with studying the different processes leading to the production of commercial uranium concentrate (yellow cake) from the mineralized ore material of El-Sela Shear zone, South Eastern Desert, Egypt. Uranium concentrate is produced by the treatment of about 25 tons from the study ore material that assaying about $580 \mathrm{ppmU}$ at Inshas Pilot Plant Unit.

In the present work, the studied lab-scale leaching and extraction conditions of the ore material under consideration are shifted to the pilot plant scale. From the latter, an average leaching efficiency exceeding $82 \%$ has been achieved. On the other hand, some difficulties being arised during pilot operations such as filtration, settling, washing and huge dilute volumes of the sulfate leach slurry, are overcome through the flocculent addition and reputed concentrations. The $\mathrm{pH}$ of prepared pregnant sulfate leach liquor is then adjusted at 1.75 and then shifted to the fixed bed ion exchange resin unit for the extraction of uranium to obtain highly pure concentrate $\mathrm{UO}_{4} \cdot 2 \mathrm{H}_{2} \mathrm{O}$. The latter would be subjected to further purification processes to prepare nuclear fuel.
\end{abstract}

\section{INTRODUCTION}

Extensive exploration programs were conducted by NMA of Egypt for the discovery of radioactive and nuclear raw materials. Of these, several uranium occurrences were discovered such as El-Sela Shear Zone, South Eastern Desert, Egypt. Accordingly, the discovered uranium ore materials should be subjected to several technological studies in both laboratory and pilot plant scales before eventual full application.

Treatment of uranium ore materials at Inchass Pilot-Plant Unit depends upon the application of the most common and efficient conventional methods of processing involving mainly grinding, agitation leaching using sulfuric acid, pan filters for solid liquid separation and then uranium recovery by fixed bed ion exchange column system( Abd ElGhany et al., 1994). The fixed bed ion exchange column is the first equipment used in uranium recovery processes and is still in use today (Maltby, 1959-1960). This system was, in fact, designed to treat clarified acid leach liquors containing 500-850 ppm U/1 (Ritcey,1993) and the flow rate is restricted to about $1 \mathrm{~m} 3 / \mathrm{m} 2$.min. to avoid pressure drop (Streat et al.,1987). The resin could possibly operate satisfactorily for periods of up to 20 years (Streat et al.,1987) where the attrition losses less than 5\% per year (Arden,1956).

Hydrogen peroxide has been used as a precipitating agent, owing to its superior selectivity towards uranyl ion in acidic media. Uranium precipitation with hydrogen peroxide produces a crystalline and easily hydrated uranium peroxide product $\left[\mathrm{UO}_{4} \cdot 2 \mathrm{H}_{2} \mathrm{O}\right]$.The 
efficiency of uranium peroxide precipitation is however influenced by the presence of some anions (Shabbir\&Tame,1974; Edwards, 1987). The $\mathrm{pH}$ range of $1.8-2.0$ during precipitation is optimal for carrying out quantitative precipitation of uranium along with minimum co-precipitation of the associated impurities, if present, in the final uranium peroxide product (Harrington\& Ruehle,1959). Addition of an alkali can promote the formation of uranium peroxide through neutralization of the $\mathrm{H}+$ ions and increasing the $\mathrm{pH}$ to its initial desired value (Shabbir\&Tame,1974; Edwards,1987; Brown,1980).

The present work deals with El-Sela shear zone mineralized ore material being mainly composed of sheared fine grained two mica granites with muscovite growth at the expense of biotite precursor. Microscopically, they are essentially composed of quartz, potash-feldspar, plagioclase, muscovite and biotite. Secondary minerals are sericite, kaolinite and chlorite. Opaques and garnet are the accessory minerals. It is interesting to mention herein that, the shear zone is characterized by sulphides pockets completely filled by alteration products of iron-oxy hydroxides material and sometimes refilled by secondary uranium minerals. Uranophane and beta-uranophane are the main uranium minerals identified in El-Sela ore material while autunite was also observed (Hanaa,2006).

The present work is actually concerned with verifying the bench scale studies as well as preparing proper uranium concentrate amount form El-Sela uranium ore material suitable for further purification processes.

\section{EXPERIMENTAL}

In this work, uranium recovery experiments are conducted to verify the optimum uranium recovery conditions of El-Sela ore material that have been determined in the laboratory as well as to investigate problems that might arise during pilot operations before full scale industrial application. These problems include separation of the coarse particles, low filtration and settling rates, increasing the concentration of the leach liquor and controlling the feed solution subjected to the ion exchange process.

The experimental works include the followings:

\section{Characterization of El-Sela Ore Material}

Representative samples from El-Sela mineralized ore materials are subjected to complete chemical analysis including both major and trace elements constitutions. Chemicals used in this study are of commercial grade except which were used for analysis that of the analytical grade. Uranium is determined by applying redox titration method against $\mathrm{NH}_{4} \mathrm{VO}_{3}$ (Hitchen,1964;Gray \& Davies, 1964). Iron was determined by titration against standard EDTA solution (Jeffery et al.,1989). The elemental relative concentration of the final product is identified by means of Environmental Scanning Electron Microscope (EDAX-SEM). The final product is subjected to X-ray diffraction technique XRD, using Philips X-ray generator model PW 3710/31, a diffractometer with automatic sample changer model PW1775. This instrument is connected to a computer system using X-40 diffraction program and ASTM cards for material identification. The $\mathrm{pH}$ values of the aqueous solutions are adjusted by using a $\mathrm{pH}$ meter (Dimiged DN-21).

\section{Processing Units and Procedures}

These include agitation leaching unit, solid liquid separation unit, ion exchange one and precipitation unit.

\section{The Agitation leaching unit}

The leaching unit in Inshas Pilot Plant consists of four steel cylindrical vessels lined with rubber and arranged in cascade. Every vessel has a conical base and a bottom outlet pipe, in addition to a valve. The leaching tanks, equipped with disc type agitator rotating at 350 r.p.m, PVC pipe lines, valves and connections. These tanks are filled with water then the ground ore is added. An air flow pipe is joined at the base of the vessel to prevent blockage of the bottom outlet pipe and valve. A sulfuric 
acid storage tank and two sulfuric acid feeding tanks are used which equipped with two centrifuge pumps one for acid pumping and the other for feeding the prepared acid leach solutions to the leaching tanks. A flow meter is incorporated before the later pump for controlling the feeding flow rates. Also two tanks of flocculant's content provided with agitators are installed.

Batches weighing $800 \mathrm{Kg}$ ore, each of them was leached using sulfuric acid of 100 $\mathrm{g} / \mathrm{l}$ concentration. Commercially concentrated sulfuric acid (about 96\%) was added to the slurry, in a ratio equivalent to the required final concentration, in which the exothermic heat is generated during the acid addition and used as a self heating the slurry. The leaching process is preceded for about $6 \mathrm{hrs}$ as agitation time.

\section{Solid-Liquid separation unit \\ Thickners}

Before feeding to the subsequent filtration step, it is worthy to mention herein that, four tanks equipped with mechanical agitators is used as thickeners. The slurry is introduced from the preceding leaching tanks to be settled out and ready for filtration.

\section{Filtration pans}

Four pan filters made of stainless steel and four filtrate storage cylinders are the main constituents of filtration unit. Each filter connected by PVC pipe lines through which the filtrate solution (loaded leach liquor) is withdrawn into the storage cylinders. This unit operated by applying a vacuum system which serves in accelerating the filtration rate. This mode of operation leads to an easy control and greater flexibility to treat high liquid flow rates on small area. This system is actually characterized by the merit of handling solids easily; a matter which renders it competitive with other systems. The main advantages of this system over other systems lie in the larger flows which can be handled and the ease of operation. The liquor is flowed from a layer to another by either a vacuum pump or simply by gravity through a perforated plate covered with a special fiber tissue downward facing holes distributing the liquor at the base of a rectangular filter.

\section{pH Adjustment tanks}

The $\mathrm{pH}$ adjustment was carried out at a tank made of plastic. The $\mathrm{pH}$ adjustment tank equipped with a mechanical stirrer and $\mathrm{pH}$ controller system for accurate $\mathrm{pH}$ adjustment. The $\mathrm{pH}$ controller system composed of dosing pump for sodium hydroxide addition, $\mathrm{pH}$ controller instrument and $\mathrm{pH}$ sensor probe electrode. Also, a decantation tank is used to decant the fine solids or precipitates before feeding to the ion exchange column series.

\section{Ion-Exchange unit}

\section{Ion-Exchange column series}

The ion-exchange column series is composed of four ion-exchange fixed bed columns for uranium concentration and partial purification. Each of them filled with about 23liters wet settled strong base anion-exchange resin namely, Amberlite IRA-400. The columns are provided with three centrifuge pumps, two of them are used for extraction while the third one is used for elution. The sulphate uranium pregnant solutions are passed through columns of anion-exchange resin for uranium recovery and concentration. Uranium is adsorbed and concentrated selectively in the form of tri-sulfate complex.

\section{Elution tanks}

Eluate preparation tanks made also of plastic and equipped with mechanical agitators to dissolve the sodium chloride and the required acid. The eluant solution is pumped to the columns by a centrifugal pump made of special plastic type for chloride resistance and the inlet pipeline is equipped with a flowmeter.

\section{Uranium precipitation unit}

The uranium precipitation is carried out in a plastic tank equipped with a mechanical agitator. The $\mathrm{pH}$ controller system composed of dosing pump for sodium hydroxide addition, $\mathrm{pH}$ controller instrument and $\mathrm{pH}$ sensor probe 
electrode. Another dosing pump is used for hydrogen peroxide addition.

Consequently, final wash, filtration and drying of the uranium concentrate (yellow cake) prepared from Inshas Pilot Plant Unit through precipitation by hydrogen peroxide was transferred to the filtration unit. The entire filtration cycle (washing and filtration) is carried out in a single pan filter. The filtrate is withdrawn and collected in the cylindrical storage tank. The other metal impurities form soluble complexes, thus thoroughly washed the impurities from the produced cake occurs in the same filter. Finally the precipitate is dried at a moderate temperature of about $110^{\circ} \mathrm{C}$ for $24 \mathrm{hrs}$ in the drying oven and transferred into a porcelain beaker.

\section{RESULTS AND DISCUSSION}

\section{Ore Material Characterization}

The chemical composition of the collected technological sample from El-Sela Shear Zone was determined (Ibrahim et al.,2010) and summarized in Table 1.

Table 1: Chemical composition of the technological sample from El-Sela box-cut (After ElAfandy )

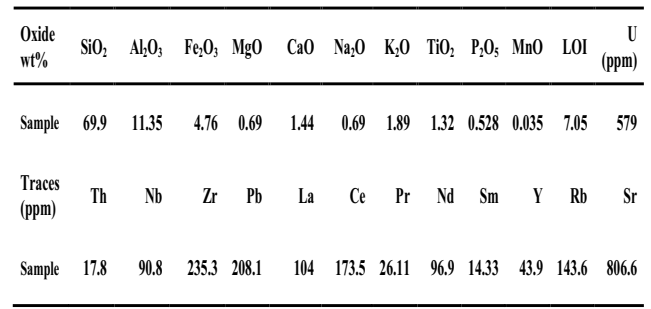

From the obtained chemical results of the study ore material, it is clearly evident that this ore material is mainly composed of $\mathrm{SiO}_{2}$ beside $\mathrm{Al}_{2} \mathrm{O}_{3}, \mathrm{Fe}_{2} \mathrm{O}_{3}, \mathrm{TiO}_{2}, \mathrm{P}_{2} \mathrm{O}_{5}$ and organic matter. The high contents of $\mathrm{Al}_{2} \mathrm{O}_{3}, \mathrm{Fe}_{2} \mathrm{O}_{3}$, $\mathrm{TiO}_{2}$ together with L.O.I reflect the intensive alteration of the sulphide - rich fine - grained granite to argillic material a matter which would reflect difficult filtration during processing. Also, relatively low $\mathrm{SiO}_{2}$ content re- garding the numerous silica injections assure the high potential dissolution process acting on the shear zone.

\section{Uranium Ore Processing}

\section{Leaching unit}

\section{Results of agitation leaching}

It is worthy to mention that through performing about 31 charges leaching experiments, no external heating was used, the temperature of the leach slurry reached more than $40{ }^{\circ} \mathrm{C}$ due to the self heat of dilution of sulfuric acid in the leaching tank. This temperature has actually been maintained during the leaching period of $6 \mathrm{hrs}$ because of good tank insulation.

The experimental lab scale data of leaching conditions at: Solids particle size -200 mesh, $300 \mathrm{~g} \mathrm{H}_{2} \mathrm{SO}_{4} / \mathrm{kg}$ ore in a solid/liquid ratio of $1 / 2$ for 4 hours agitation time at $35^{\circ} \mathrm{C}$ reached a dissolution efficiency of $71.4 \%$ or $95.8 \%$ at $100^{\circ} \mathrm{C}$ ( Hanaa,2006). Ibrahim, et al., (2007) indicated that optimum U dissolution efficiency of $95.8 \%$ upon $50 \mathrm{~g}$ rock sample grinded to a -60 mesh size has been achieved after conducting $300 \mathrm{~g} / \mathrm{H} \mathrm{H}_{2} \mathrm{SO}_{4}$ with the study rock material in a manner to have a $\mathrm{S} / \mathrm{L}$ ratio of $1 / 2$, 4hrs as leaching time and $100{ }^{\circ} \mathrm{C}$ as pulp temperature or $8 \mathrm{hrs}$ leaching time at room temperature. Another lab scale leaching conditions were reported by Abdel Gany, (2008, personal communication); the grinded ore material at -18 mesh, sulfuric acid concentration of about $120 \mathrm{~g} / \mathrm{l}$ and the leach acid/ore ratio of about $1.23,50 \%$ hydrogen peroxide as oxidant, a temperature of $45^{\circ} \mathrm{C}$ and the leaching process continued for $8 \mathrm{hrs}$ which reached a dissolution efficiency of $89.3 \%$.

In the present work, the optimum leaching conditions obtained by Abdel Gany (2008) are applied as the sulfuric acid concentration used, relatively low beside the use of the relatively coarse grained ore of -18 mesh size. These results are compared to pilot scale conditions data. The working pilot scale leaching parameters are kept constant at: solids particle 
size -16 mesh, every charge weighed about $800 \mathrm{~kg}, 100 \mathrm{kgH}_{2} \mathrm{SO}_{4} /$ ton ore, liquid/solid ratio $2: 1$, and agitation time for $6 \mathrm{hrs}$. Results of the leaching experiments that are conducted in Inchass Pilot Plant ( Table 2).

It is found necessary to run the washing step in order to obtain the residual leach liquor. Tap water is used to wash the cake after leaching at a cake/water ratio of $1 / 1$. Averages of $U$ concentration of the successive wash cycles that are conducted in Inchass pilot plant (Table 3).

Table 2 : Uranium concentration in the obtained sulphate leach liquor of the treated 25 tons of ElSela uraniferous ore material

\begin{tabular}{lrrr}
\hline & $\mathrm{pH}$ & $\begin{array}{r}\mathrm{U} \text { concentration, } \\
\mathrm{g} / \mathrm{l}\end{array}$ & $\begin{array}{r}\mathrm{Fe}_{2} \mathrm{O}_{3} \\
\mathrm{~g} / \mathrm{l}\end{array}$ \\
\hline Leach Liquor & & & \\
Mean Values & 0.80 & 0.23 & 2.21 \\
\hline
\end{tabular}

Table 3 : Average uranium concentration in the successive wash cycles obtained by the treatment of 25 tons tons of El-Sela uraniferous ore material

\begin{tabular}{|c|c|c|c|c|}
\hline & \multicolumn{4}{|c|}{ Uranium Concentration in the successive wash cycles, } \\
\hline & C1 & C2 & C3 & C4 \\
\hline Mean Values & 0.11 & 0.076 & 0.042 & 0.018 \\
\hline
\end{tabular}

From these Tables (2\&3), it can be concluded that, uranium recovery efficiency in the leaching circuit reached more than $82 \%$; i.e. the uranium recovery efficiency after leaching and washing reached about $475 \mathrm{ppm}$, with an average acid consumption attained about $40 \mathrm{kgH}_{2} \mathrm{SO}_{4}$ /ton ore where the remainder unleached part is considered for some types of refractory uranium minerals that require sever conditions for leaching. However, this level of leaching is considered quite satisfactory compared to the related applied methods in the world uranium mills.

\section{Effect of oxidant addition}

In a trial to improve $U$ leaching efficiency from the study ore material, different quantities of $50 \%$ hydrogen peroxide $(1,2,5,7$, 10 and $15 \mathrm{ml} /$ liter slurry) are added in the leaching step to test its effect on the uranium extraction efficiency. It is realized that a rare effect was detected with the addition of hydrogen peroxide even by increasing its added volume. This result is confirmed with the fact of the presence of the uranium minerals in El-Sela rocks as secondary minerals (uranophane, beta uranophane and autunite).

\section{Solid liquid separation unit \\ Effect of flocculent addition}

When performing the filtration step without any flocculent addition, it is found that the clear solution level did not exceed $10 \%$ of the slurry in the thickening tanks in spite of the time left for settling reached $24 \mathrm{hrs}$. This is explained as due to the relative fineness of input ore and excess of the clay in the ore materials, and hence the filtration rates of the pilot leaching tests have been found too low for practical application.

This problem was successfully overcome by using a neutral type polyacrylamide as a flocculent. The flocculent agent polyacrylamide is added with different concentrations to the leaching pulp slurry to expedite settling and accelerate the slurry filtration. This addition is decided due to the presence of gangue clayey materials. Different experiments are conducted by using flocculent concentrations of $1 \mathrm{~g}$ flocculent/150lit slurry, 100lit, 75lit, 50lit, 25lit, 15lit, 10lit, and 5lit. slurry to test the settling rate in two plastic flocculant's tanks.

From the obtained results of flocculent addition, it is found that a concentration of $1 \mathrm{~g}$ flocculent /25 liter slurry verify complete settling in a settling time period of 6-8hrs. By increasing the flocculent concentration over this value, the same level of the clear solution of half tank is obtained. This result is 
considered as a time saving, from one hand, and increasing the volume of the clear solution which was used in the subsequent step through the ion-exchange resin from the other hand.

\section{Coarse size particles separation}

To facilitate the solid/liquid separation step, the coarse particles should be separated from the fine ones. It is worthy to represent that due to the treatment of El-Sela uranium ore ground to -16 mesh, and after passing the required agitation time of $6 \mathrm{hrs}$, the agitators of the leaching tanks are stopped. After two minutes for a quick settling, the slurry is withdrawn from the outlet upper side being somewhat over the lower one of the tank. This process of stirring and settling is repeated several times with the addition of wash water to prevent the coarse particles to pass out with the slurry in the settling tanks to overcome the problems arising from the presence of the coarse particles in the pipelines. The heavy coarse particles are contained several heavy metals could be recovered by another process.

\section{Preparation of feed solution}

Upgrading of uranium leach liquor content

Due to the relatively low uranium content about $80 \mathrm{ppm}$ in El-Sela uranium ore material and the corresponding leach liquor after washing, a matter would required to reduce the leach liquor volume and increase its $U$ concentration. For this purpose, the following steps were applied:

1) The leach liquor withdrawn from the thickeners is neutralized with the addition of concentrated sodium hydroxide solution. The slurry is precipitated then left to be settled out. The neutralized clear solution free of uranium is withdrawn to disposal.

2) A new batch of the leach liquor is then poured to the contractive neutralized cake. The slurry is agitated, re-neutralized with sodium hydroxide for another run and then the uranium free solution is spilled out to disposal.

These steps are repeated for 3-5 times till the precipitated cake occupied about three quarters of the tank. Fresh pregnant leach liquor is then used to be added to the neutralized precipitated cake of higher uranium content to economize sulfuric acid addition and consequently less expense. This fresh solution is agitated with the precipitate and then the $\mathrm{pH}$ is adjusted at 1.75 being the required solution $\mathrm{pH}$ subjected to the ion-exchange resin. As a result, pregnant leach liquor of about $0.28 \mathrm{gU} /$ 1 was obtained of higher uranium content with smaller volumes.

\section{pH Adjustment of pregnant leach liquor}

From the results indicated on Fig.1 that are realized during the lab-scale studies, it is decided to operate the $\mathrm{pH}$ adjustment at 1.75 with sodium hydroxide concentrated solution before the uranium extraction step by the anion exchange resin.

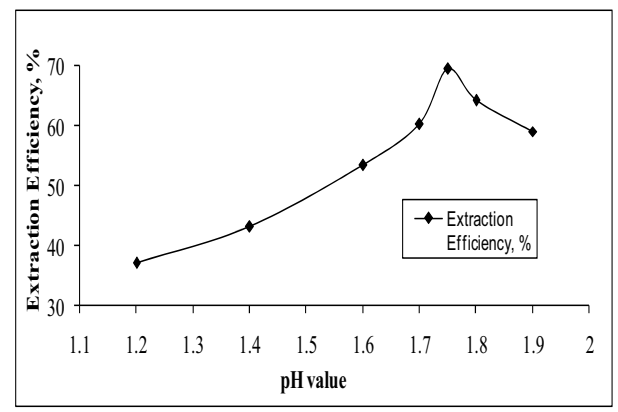

Fig. 1: Effect of pregnant leach liquor $\mathrm{pH}$ on the uranium extraction efficiency

This is because above $\mathrm{pH} 1.9$, it has been realized that white precipitate is appeared which create a serious problem in the extraction process. It may be precipitated in the interstitial spaces between the resin beads leading to clogging in the extraction columns. However, the uranium concentration in the pregnant leach liquor decreased as a result of the precipitation of uranium which may form a complex with iron phosphate. A sample of the white precipitate from the pregnant leach liquor at $\mathrm{pH}$ equals 2 is filtered, dried and analyzed using SEM microscope to determine its content (Fig. 2). 


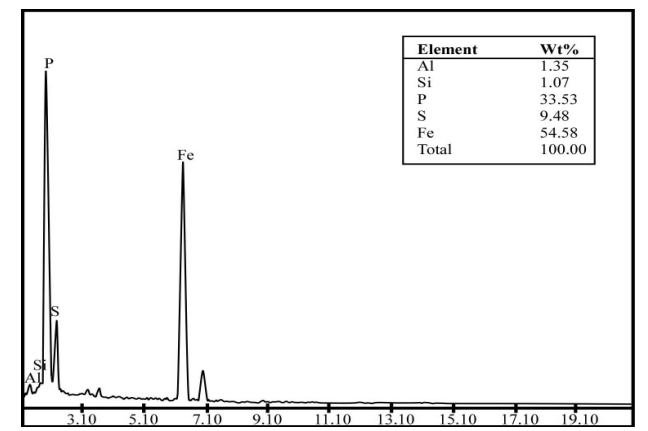

Fig. 2: SEM spectrum for precipitate from the pregnant leach liquor at $\mathrm{pH} 2$

In the present work, uranium leaching solution of about $42 \mathrm{~m}^{3}$ at $\mathrm{pH}$ about 0.8 is then adjusted at a $\mathrm{pH}$ which would verify maximum extraction efficiency (1.75) using $10 \%$ sodium hydroxide solution when the stream of the pregnant leach liquor pass through the ion exchange column. The adjusted leaching solutions were left over night in the settling tank to permit the precipitation of fine slimes to be settled out. The clear adjusted solutions are withdrawn and transferred to another feeding tank to be introduced to the anion exchange columns. However, the U concentration in the pregnant solution is indicated in Table (4).

Table 4: Composition of the Pregnant Feed Solution

\begin{tabular}{lrrrr}
\hline & $\mathrm{pH}$ & $\begin{array}{r}\mathrm{U} \\
\text { concentration, } \\
\mathrm{g} / \mathrm{l}\end{array}$ & $\begin{array}{r}\mathrm{Fe}_{2} \mathrm{O}_{3} \\
\mathrm{Concentration,} \\
\mathrm{g} / \mathrm{l}\end{array}$ & $\begin{array}{r}\mathrm{SO}_{4}^{-} \\
\mathrm{g} / \mathrm{l}\end{array}$ \\
\hline $\begin{array}{l}\text { Pregnant Solution } \\
\text { Mean Values }\end{array}$ & 1.75 & 0.28 & 1.82 & 4.1 \\
\hline
\end{tabular}

Ion exchange unit

\section{Results of uranium loading efficiency}

A pregnant solution flow rate of 60 lit./ $\mathrm{hr}$, detected with a flowmeter, was decided to pass through the ion exchange column as the rafinate effluent solution was barren. By increasing the flow rate above this value, it is observed that some uranium content escaped in the effluent solution.

In the present work, the obtained working capacity of the study resin is reaching about
$68 \mathrm{gU} / 1$ (w.s.r). Referring to the resin theoretical capacity determined by (El-Hazek, 1965) of $1.56 \mathrm{meq} / \mathrm{ml}$ (w.s.r) while gives for the U tetravalent tri-sulphate complex a capacity of about $92.8 \mathrm{gU} / 1$ (w.s.r). The obtained relatively low working capacity may be due to the relatively low $U$ content relative to sulfate and iron concentrations in the prepared sulfate leach liquor and hence, the Fe and some other elemental species will be co-adsorbed with $\mathrm{U}$. The obtained adsorption data are presented in Table (5). The shape of the effluent concentration profile (Breakthrough Curve),(Fig. 3) from an ideal bed would be similar to that of the influent concentration profile, with a time lag accounting for the residence time within the bed.

Table 5: Uranium loading of pregnant solutions of one batch from three batches on ion exchange resin columns pilot plant $(\mathrm{pH} 1.75,280 \mathrm{ppm}$, $1.82 \mathrm{gFe} /$ liter "as mean values", $601 / \mathrm{hr}$ )

\begin{tabular}{lrr}
\hline $\begin{array}{l}\text { Volume throughput } \\
\text { No., (1000 liters) }\end{array}$ & $\begin{array}{r}\text { Effluent Uranium } \\
\text { Content, } \\
\text { ppm }\end{array}$ & $\begin{array}{r}\text { Extraction } \\
\text { Efficieny, } \\
\%\end{array}$ \\
\hline $1-9$ & 0 & 100 \\
10 & 3 & 99 \\
11 & 25 & 91 \\
12 & 56 & 80 \\
13 & 106 & 62 \\
14 & 185 & 34 \\
\hline
\end{tabular}

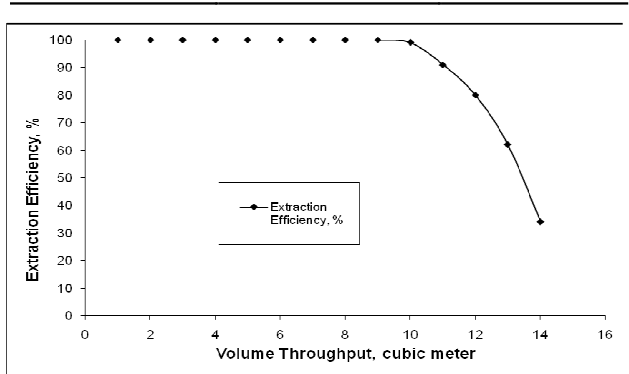

Fig.3: Breakthrough curve for uranium extraction

After extraction, the loaded resin is then washed by 100 liters acidified water of a $\mathrm{pH} 1.75$ before the elution step. The washing step aims to free the resin beads from the leach liquor as well as free the resin beads from any accumulated solids or precipitates. For this purpose, two tanks made of stainless steel equipped with a mechanical agitator are used. 


\section{Results of uranium elution}

Elution of uranium from the loaded strongly basic anion exchange resin is normally carried out by sodium chloride solution of $1 \mathrm{M}$ acidified with about $0.15 \mathrm{M}$ hydrochloric acid. The eluant passed downwards the loaded resin with a flow rate of $0.3 \mathrm{li}$ ter/min. The eluant volume throughput was about 650 liters which are obtained after about 36 hours of eluant solution streaming. The uranium concentrations in the eluate are tabulated in Table (6) and the uranium elution profile is shown on Fig. 4. The elution step is decided to be stopped when the produced uranyl sulfate solution concentration is then reached down to less than $1 \mathrm{~g} /$ lit. to prevent large volumes of low concentrations. The fractions of high $U$ content will be directed to the precipitation circuit. After this elution step the working four ion exchange fixed bed columns are washed with acidified water to enable them to another re-extraction process.

Table 6: Uranium concentration in the eluate of one batch from three batches using $1 \mathrm{M} \mathrm{NaCl}, 0.15 \mathrm{M} \mathrm{HCl}$ at a Flow Rate of 181 iter $/ \mathrm{hr}$

\begin{tabular}{lr}
\hline $\begin{array}{l}\text { Eluate Volume } \\
\text { Throughput } \\
\text { No. } \\
\text { (50 liters) }\end{array}$ & $\begin{array}{r}\text { Uranium } \\
\text { concentration, } \\
\text { g U/l }\end{array}$ \\
\hline 1 & 0.9 \\
2 & 2.1 \\
3 & 4.1 \\
4 & 6.0 \\
5 & 7.3 \\
6 & 8.8 \\
7 & 9.8 \\
8 & 8.2 \\
9 & 5.9 \\
10 & 4.3 \\
11 & 2.5 \\
12 & 1.5 \\
13 & 0.7 \\
\hline
\end{tabular}

\section{Uranium precipitation, washing,} filtration and drying

To produce uranium concentrate, known commercially as "yellow cake", from eluate solutions, Inchass pilot plant unit was initially designed to apply direct and selective

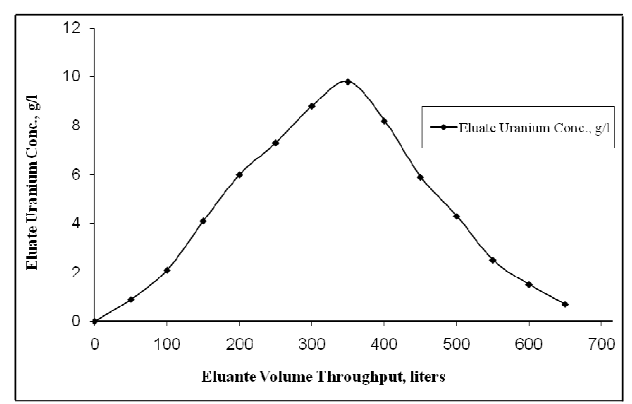

Fig. 4 : Uranium elution profile from the loaded Amberlite IRA-400 anion exchange resin

precipitation of uranium concentrate in one stage using hydrogen peroxide. After the addition of hydrogen peroxide and the subsequent final $\mathrm{pH}$ adjustment to the required value, the precipitated slurry should be allowed to stand for a reaction time of $2-4 \mathrm{hrs}$ to achieve complete precipitation.

Washing is achieved using distilled water at a ratio of 15 to the cake with addition of a few drops of hydrogen peroxide to prevent uranium dissolution. The wash water containing some uranium species is recycled to be used in a next elution step.

The thickened cake after filtering and final wash with water is dried at a moderate temperature of about $110{ }^{\circ} \mathrm{C}$ for $24 \mathrm{hrs}$ in the dryer.

\section{Yellow cake specifications}

Uranium concentrate was produced by the treatment of 25 tons of uranium ore materials from El Sela Shear Zone, South Eastern Desert, Egypt in Inshas Pilot Plant Unit.

The yellow cake specifications obtained from 25 tons of El-Sela uraniferous ore materials are tabulated in the Table (7).

The uranium concentrate is obtained as $\mathrm{UO}_{4} \cdot 2 \mathrm{H}_{2} \mathrm{O}$ in which $\mathrm{U}$ was analysed and reached $59.0 \%$ while the moisture content is $5.5 \%$ and other elements of $3.1 \%$ such as $\mathrm{Fe}^{+}$, $\mathrm{SO}_{4}^{-2}, \mathrm{Cl}^{-}, \mathrm{Na}^{+}$...etc.. The dried yellow cake end product was also identified by means of scanning electron microscope (Fig.5). 
Table 7: Yellow cake specifications obtained from 25 tons of El-Sela uraniferous ore material

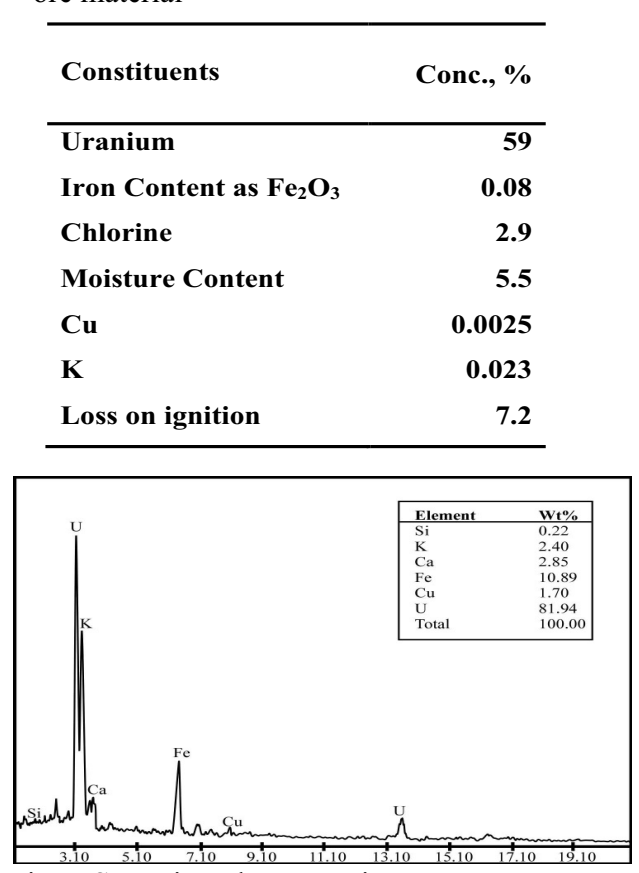

Fig 5: Scanning electron microscope EDX spectrum for the yellow cake end product

\section{CONCLUSIONS}

From this work, the followings can be concluded:

1- The problem of the low filtration and settling rates was successfully overcome by using a neutral type polyacrylamide as a flocculent with a concentration of $1 \mathrm{~g}$ flocculent /25 liter slurry which verify complete settling in a settling time period of 6-8hrs.

2- Also, the problem arising from the presence of the coarse particles in the pipelines was solved by repeating the stirring then quick settling and withdrawing the slimes.

3- The relatively low uranium concentration of about $80 \mathrm{ppm}$ in the leach liquor after washing was solved through the reduction of leach liquor solution volumes. As a result, pregnant leach liquor of about $0.280 \mathrm{gU} / 1$ was loaded upon the ion exchange resin to obtain higher uranium content with smaller volumes.

The obtained capacity of the study working resin was relatively low of about $68 \mathrm{gU} / 1$ (w.s.r.). The produced yellow cake was in the form of $\mathrm{UO}_{4} \cdot 2 \mathrm{H}_{2} \mathrm{O}$.

Finally, a flow diagram is proposed (Fig.6) for the treatment of the worked ore material starting with acidic agitation leaching using $\mathrm{H}_{2} \mathrm{SO}_{4}$ through anion exchange resin and ended with uranium precipitation as uranium peroxide.

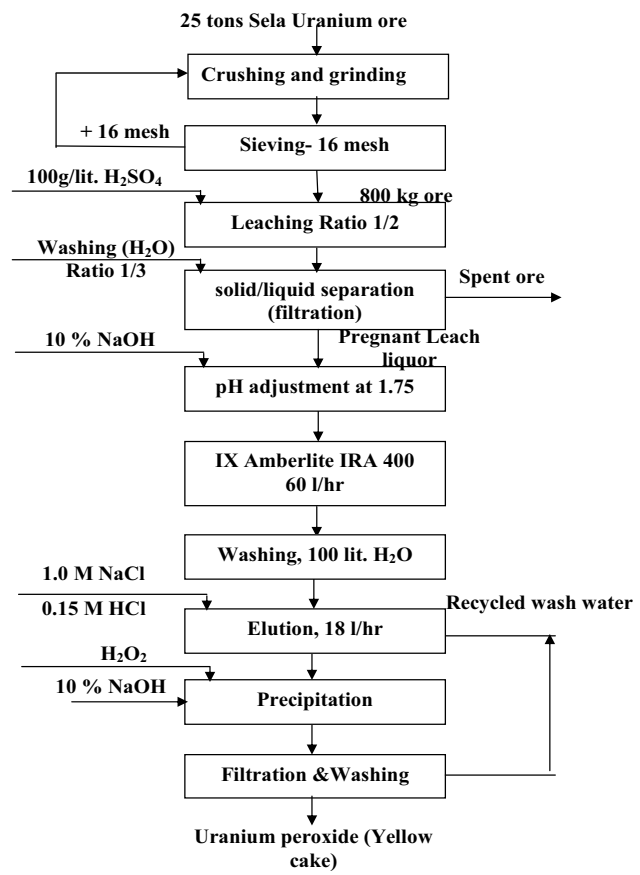

Fig. 6 : Flow diagram for the treatment of El Sela ore materials at Inshas Pilot Plant Unit

\section{REFERENCES}

Abd El-Ghany, M.S.; Mahdy, M.A.; Abd ElMonem, N.M., and El-Hazek, N.T.,1994. Pilot Plant Studies on the Treatment of E1 Atshan Uranium Ores, Eastern Desert, Egypt. 2nd Arab Conf. Peaceful Uses of Atomic Energy, AAEA, Cairo.

Arden, T.V., 1956. The Recovery of Uranium 
from Sulfate Leach Solutions by Anion Exchange. Proc. Symp. Extract. Metall., Inst. Min. \& Metall., London.

Brown, R.,1980. Proc. of AIME Annual Meet., Nevada .

Edwards, C., 1987. Crystallization and Precipitation. Proc. Symp., Toronto, Pregamon Press.

El Hazek, N. M. T.,1965. Studies on the leachability and uranium concentration of ElAtshan and comparable ores in relation to mineralogical composition. M. Sc. Thesis, Ain Shams Univ., Egypt.

Gray, W.; Davies, W.,1964. A Rapid and Specific Volumetric Method for the Precise Determination of Uranium. TRG Report 716(D), Bombay, India.

Hanaa, A.A,2006. Geochemistry And Processing Of Some Valuable Metals From Mineralized Two Mica Granites, South Eastern Desert, Egypt. M. Sc. Thesis, Fac. Sci., Cairo Univ.

Harrington, C., and Ruehle, A., 1959. Uranium Production Technology. D. Van Nostrand, New Jersey.

Hitchen, A., A.,1964. Manual of Analytical Methods Used by the Canadian Mining Industry. Chemical Analysis Section, Extraction Metallurgy Division, Department of Energy, Mines and Resources, Ottawa,
(Part two).

Ibrahim, T.M.M.; Abd El-Ghany, M.S.;Ali, K.G., and Gaffar, I.M.E.,2010. Characterization of a New Surficial Uranium Deposit in El Sela Granite, South Eastern Desert, Egypt. N.M.A., Egypt .

Ibrahim, T. M.M.; Amer, T. E.; Ali, K. G., and Omar, S. M, 2007.Uranium Potentiality and its extraction from El Sela shear zone, south Eastern Desert Egypt. Sci. Fac. Minufia Univ., XXI, 1-18.

Jeffery, G.H.; Bassett, J.; Mendham, J., and Denney, R.C.,1989. Vogel's Textbook of Quantitative Chemical Analysis. 5th edition, John Wiley \& Sons, Inc., New York..

Maltby, P.D.D.,1959-1960. Use of Moving Bed Ion Exchange in the Recovery of Uranium at Can-Met Explorations Ltd., Blind River, Ontario. Trans. Inst. Mining Metall., London .

Ritcey, G.M.,1993. Uranium Extraction Technology. Tech. Rep. Ser. no. 359, IAEA, Vienna.

Shabbir, M.; Tame, K.E., 1974.Hydrogen Peroxide Precipitation of Uranium, U.S. Bureau of Mines, Salt Lake City, Utah. Report of Investigations 7931 .

Streat, M., and Naden, D.,1987. Ion Exchange in Uranium Extraction. Critical Reports on Appl. Chem.,19, Ion Exchange and Separation Processes in Hydrometallurgy. 


\section{استعادة اليورانيوم من منطقة القص السيلا- جنوب الصحراء الثرقية ـ مصر، في الوحدة النصف صناعية بانشاص الفئل}

$$
\text { ياسر محمود خو اسك }
$$

يتعرض العمل الحالي لدر اسة العمليات المختلفة التى تؤدي إلى إعداد تركيز من اليور انيوم التجاري (الكعكة الصفر اء). نم إنتاج ركاز اليور انيوم بمعالجة حوالي خمسة وعشرين طن من المواد الدئ الخام

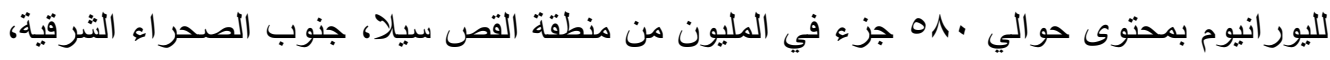

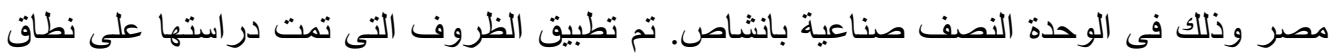

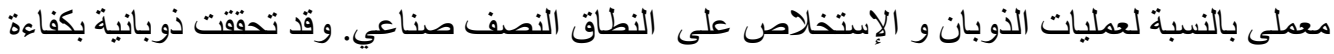

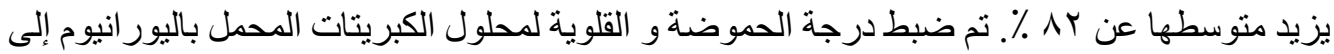

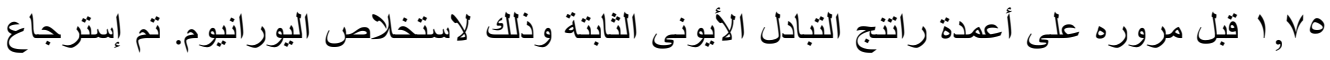
اليور انيوم بواسطة كلوريد الصوديوم ثم ترسيبه بواسطة فوق أكسيد الهيدروجين و أخير ا تم تجفيفه. تم الحصول على ركاز اليور انيوم فى صورة

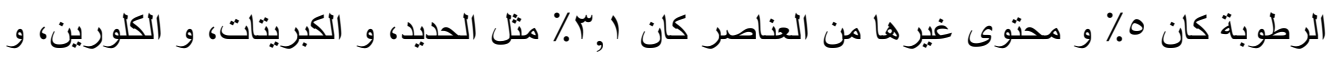

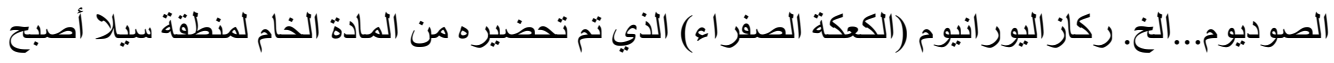
مناسبا لمزيد من عمليات التنقية و ذللك لتحضير الوقود النورئ النووي. 